\title{
Upaya Peningkatan Hasil Belajar Lompat Jauh Melalui Pendekatan Bermain Lompat Tali pada Siswa Kelas IV Sekolah Dasar
}

\author{
Y. Warsiyanti* \\ SD Negeri 2 Katekan Kecamatan Gantiwarno Kabupaten Klaten \\ *warsiyanti@gmail.com
}

\begin{abstract}
The students' long jump learning outcomes still do not meet the KKM. This study aims to describe the process of improving long jump learning outcomes through the rope jumping approach to fourth grade students of Katekan 2 Elementary School in Gantiwarno District, Klaten Regency. This research is a classroom action research. The subjects in this study were grade IV students of SDN 2 Katekan in Gantiwarno District, Klaten Regency with a total of 20 students. The instrument used was a long jump performance test. The data analysis technique used in this study is descriptive qualitative and quantitative. Based on the results of the study, it can be concluded that the effort to increase the results of the long jump through rope jumping in the fourth grade students of Katekan Elementary School 2 of Gantiwarno Subdistrict, Klaten Regency was successfully marked by an increase in the average value of students. The average value of students in pre-action activities was 55.94 with a percentage of completeness of $40 \%$. This condition experienced an increase in the average value of students in the first cycle, namely to be equal to 65.63 and the percentage of completeness by $60 \%$. However, this increase has not yet reached the target set previously. Then after proceeding to the second cycle the students' long jump average value increased to 70.50 with the percentage of completeness of $90 \%$. This shows that the previously set target has been reached so that the research is stopped in cycle II. The long jump learning process using the play approach takes place dynamically and pleasantly. Students actively carry out the task and observe the movement of the long jump technique and discuss each other with friends. All aspects of assessment are mastered by students. The students' long jump ability increases with the marked by all KKM complete students (Minimum Completion Criteria), namely 67.
\end{abstract}

\begin{abstract}
Abstrak: Hasil belajar lompat jauh siswa saat ini masih belum memenuhi KKM. Penelitian ini bertujuan untuk mendeskripsikan proses peningkatan hasil belajar lompat jauh melalui pendekatan bermain lompat tali pada siswa kelas IV SD Negeri 2 Katekan Kecamatan Gantiwarno Kabupaten Klaten. Penelitian ini merupakan penelitian tindakan kelas. Subjek dalam penelitian ini adalah siswa kelas IV SD Negeri 2 Katekan Kecamatan Gantiwarno Kabupaten Klaten dengan jumlah total 20 siswa. Instrumen yang digunakan yaitu tes unjuk kerja lompat jauh. Teknik analisis data yang digunakan dalam penelitian ini adalah deskriptif kualitatif dan kuantitatif. Berdasarkan hasil penelitian maka dapat disimpulkan bahwa upaya peningkatan hasil lompat jauh melalui bermain lompat tali pada siswa kelas IV SD Negeri 2 Katekan Kecamatan Gantiwarno Kabupaten Klaten telah berhasil ditandai dengan peningkatan nilai rata-rata siswa. Nilai rata-rata siswa pada kegiatan pratindakan sebesar 55,94 dengan persentase ketuntasan sebesar $40 \%$. Kondisi tersebut mengalami peningkatan nilai rata-rata siswa pada siklus I yaitu menjadi sebesar 65,63 dan persentase ketuntasan sebesar $60 \%$. Namun, peningkatan tersebut masih belum mencapai target yang ditetapkan sebelumnya. Kemudian setelah melanjutkan ke siklus II nilai rata-rata lompat jauh siswa kembali mengalami peningkatan menjadi sebesar 70,50 dengan persentase ketuntasan sebesar $90 \%$. Hal tersebut menunjukkan bahwa target yang telah ditetapkan sebelumnya sudah tercapai sehingga penelitian dihentikan pada siklus II. Proses pembelajaran lompat jauh menggunakan pendekatan bermain berlangsung dinamis dan
\end{abstract}


menyenangkan. Peserta didik aktif melaksanakan tugas dan mengamati gerakan teknik lompat jauh dan saling diskusi dengan teman. Seluruh aspek penilaian dikuasai peserta didik. Kemampuan lompat jauh peserta didik meningkat dengan ditandai dengan seluruh peserta didik tuntas KKM (Kriteria Ketuntasan Minimal) yaitu 67.

Kata Kunci: peningkatan, hasil belajar, lompat jauh, bermain.

\section{Pendahuluan}

Tujuan Pendidikan Nasional menurut UU No. 20 tahun 2003 pasal 3 adalah mengembangkan potensi peserta didik supaya menjadi manusia yang beriman, bertaqwa kepada Tuhan Yang Maha Esa, berahklak mulia, sehat, berilmu, cakap, kreatif, mandiri dan menjadi warga negara yang demokrasi serta bertanggung jawab. Ini merupakan tanggung jawab bersama khususnya guru untuk turut mencerdaskan bangsa, diantaranya melalui pendidikan formal mulai dari sekolah dasar sampai perguruan tinggi. kegiatan belajar merupakan kegiatan yang amat komplek bukan saja menyangkut aspek kejiwaan tetapi juga aspek fisik, maka guru harus berupaya semaksimal mungkindalam menata lingkungan belajar dan perencanaan materi pembelajaran yang matang agar terjadi proses pembelajaran yang efektif baik itu didalam maupun diluar kelas guru harus mengenal substansi yang dipelajari menyangkut aspek kognitif, afektif dan psikomotor.

Sekolah sebagai salah satu institusi pendidikan secara langsung bertanggung jawab penuh terhadap kinerja pendidikan yang berkualitas serta mampu membenahi segala aspek yang menjadi wewenang dalam pelaksanaan manajemensekolah. Diantaranya adalah melalui peningkatan proses pembelajaran agar menjadi lebih bermutu sesuai dengan kompetensi yang akan dicapai. Proses pembelajaran yang diterapkan harus memperhatikan spesifikasi dari karateristik mata pelajaran serta perkembangan peserta didik sehingga tercipta suasana dilapangan yang kondusif, menyenangkan, efektif dan tampak semangat dalam mengikuti pelajaran.

Pembelajaran menurut Romiszowski sebagaimana dikutip Udin S Winataputra adalah proses membuat orang melakukan proses belajar sesuai dengan rancangan [1]. Pendapat Lingren dikutip oleh Udin S Winataputra, bahwa dilingkungan sistem pendidikan mencakup tiga faktor yang menentukan, yaitu: (a) Siswa, sebab tanpa siswa tidak terjadi proses belajar; (b) Proses belajar, yaitu apa saja yang dihayati oleh siswa pada saat mereka belajar, bukan apa yang harus dilakukan guru untuk mengajarkan materi pelajaran, tetapi apa yang akan dilakukan oleh siswa untuk mempelajarinya; (c) Situasi belajar, yaitu lingkungan tempat terjadinya proses belajar [1].

Salah satu komponen utama pada proses pembelajaran adalah pendekatan pembelajaran. Pendekatan pembelajaran berfungsi sebagai cara dalam penyajian isi pembelajaran atau merupakan kegiatan yang dipilih guru dalam proses pembelajaran guna memberikan kemudahan kepada siswa menuju tercapainya tujuan yang telah ditetapkan. Pendekatan dalam pembelajaran pendidikan jasmani adalah merupakan cara atau jalan yang ditempuh untuk menyajikan tugas-tugas ajar yang ada dasarnya berupa kerja fisik dan keterampilan. Dalam hal ini guru pendidikan jasmani perlu mempertim-bangkan, pendekatan pembelajaran yang paling tepat sehingga keterampilan itu dapat dikuasai dalam waktu yang tidak terlalu lama. Menurut Rusli Lutan, dkk., bahwa pendekatan pembelajaran dalam pendidikan jasmani ada dua yaitu: (1) Strategi yang berpusat pada guru (strategi komando) dan, (2) Strategi yang berpusat pada siswa (strategi inkuiri) [2].

Siswa SD merupakan siswa yang masih dalam tahap bermain. Oleh karenanya diperlukan suatu metode pembelajaran yang mengacu pada anak bermain. Kegiatan pembelajaran atletik pada mata pelajaran pendidikan jasmani dan kesehatan yang bernuansa permainan menyediakan pengalaman gerak yang komplit, yang akan membangkitkan motivasi pada siswa untuk berpartisipasi aktif dalam pembelajaran [3].

Lebih lanjut menurut Yudha M. Saputra, kegiatan bermain dalam pembelajaran memiliki ciriciri sebagai berikut:

1) Siswa terlibat dalam tugas gerak yang bervariasi dengan irama tertentu.

2) Membangkitkan kegemaran berlomba/berkompetisi/bersaing secara sehat. 
3) Menyalurkan hasrat siswa untuk mencoba menggunakan alatalat berlatih.

4) Tugas gerak yang mengandung resiko yang sepadan dengan kemampuan siswa dan menjadi tantangan.

5) Kepuasan siswa untuk memperlihatkan ketangkasan/ keterampilannya.

6) Menguji ketangkasan untuk melaksanakan tugas-tugas gerak yang baru

Dalam pembelajaran loncat jauh di Sekolah Dasar, permainan yang dirasa cocok untuk siswa dapat berlatih adalah dengan menggunakan lompat tali. Olahraga lompat tali merupakan olahraga yang mengunakanseutas tali untuk melakukan lompatan. Menurut Bayu Surya lompat tali dikenal dengan istilah rope skipping [4]. Lompat tali adalah suatuaktivitas yang menggunakan tali dengan kedua ujung tali dipegangdengan kedua tangan lalu diayunkan melewati kepala sampai kaki sambilmelompatinya. Menurut Chrissie Gallagher (2006: 99) lompat tali atauskipping adalah suatu bentuk latihan CV (Cardio Vaskuler) yang sangatbaik karena dapat menjadikan sebuah latihan yang sangat berat dan dapatmeningkatkan daya tahan dan kecepatan [5].

Menurut Muhamad Muhyi Faruq sasaran atau tujuann lompat tali adalah: (1) mengembangkan daya tahan, (2) mengembangkankekuatan kaki dan lengan, (3) mengembangkan kekuatan kardiovaskuler,(4) membantu memahami ritme gerakan melalui aktivitas ini, (5)membantu kordinasi gerakan tangan dan kaki, (6) mengembangkan keseimbangan tubuh [6]. Pendapat senada juga disampaikan oleh SoetotoPontjopoetro menyatakan bahwa tujuan lompat taliadalah: (1) melatih keterampilan melompat dan meloncat, (2) melatihkoordinasi antara kedua tangan dan kaki, (3) melatih otot tungkai agardapat hasil lompatan yang baik [7].

Proses pembelajaran yang diharapkan mengandung 4 ranah atau aspek yaitu: kognitif, afektif, psikomotorik dan manipulatif. Seiring dengan kemajuan di dunia pendidikan, muncul banyak metode pembelajaran yang dapat menjadi salah satu alternatif pemecahan dari permasalahan pembelajaran yang ada saat ini, sekaligus dapat digunakan untuk menciptakan suksesnya tujuan pembelajaran. Meskipun begitu, metode pembelajaran belum banyak diterapkan di sekolah karena guru belum banyak yang mempelajari metode-metode pembelajaran. Memberikan pembelajaran atletik yang menarik, praktis dan diminati siswa adalah tugas seorang guru, khususnya guru penjaskes. Oleh karena itu guru harus mampu menyesuaikan kebutuhan yang berhubungan dengan siswa dan materi pembelajaran tersebut. Guru juga harus mampu menerapkan pendekatan, model, metode dan strategi yang sesuai dengan materi pembelajaran yang akan disampaikan.

Atletik adalah cabang olah raga yang paling tua dan merupakan induk dari semua cabang olah raga yang gerakannya merupakan ragam dan pola gerak dasar hidup manusia [8]. Gerakan-gerakan dalam atletik adalah gerakan yang dilakukan manusia sehari-hari. Atletik diartikan sebagaiaktivitas jasmani atau latihan fisik, berisi gerakan-gerakan alamiah dasar atau wajar seperti jalan, lari, lompat dan lempar.

Atletik merupakan olahraga yang diajarkan di sekolah-sekolah, salah satu cabang atletik yang diajarkan adalah lompat jauh. Lompat jauh adalah keterampilan gerak dari satu tempat ke tempat lain dengan satu kali tolakan ke depan sejauh mungkin. Untuk itu diperlukan penguasaan teknik lompatan, serta mematuhi peraturan guna mencapai hasil dalam lompat jauh. Ada 4 (empat) teknik lompatan yang merupakan rangkaian gerakan yang terdiri dari: teknik awalan, teknik tolakan, teknik sikap badan di udara dan teknik sikap waktu mendarat.

Lompat jauh adalah suatu bentuk gerakan melompat mengangkat kaki ke atas, ke depan dalam upaya membawa titik berat badan selama mungkin di udara (melayang di udara) yang dilakukan dengan cepat dan dengan jalan melakukan tolakan pada satu kaki untuk mencapai jarak yang sejauh-jauhnya. Agar prestasi di bidang atletik khususnya lompat jauh bisa maksimal maka yang perlu diketahui adalah adanya beberapa aspek yang mempengaruhi seperti aspek biologis, kemampuan dasar tubuh, fungsi organ tubuh, postur dan struktur tubuh serta aspek gizi [9]. Oleh sebab itu pembinaan atlet lompat jauh harus memperhatikan beberapa faktor yang secara potensial ikut berperan dalam pencapaian prestasi lompat jauh.

.Menurut Murniasari unsur-unsur pokok lompat jauh yang meliputi awalan, tolakan, tumpuan, dan mendarat adalah merupakan aktivitas gerakan yang merupakan satu kesatuan gerakan yang berurutan dan tidak terputus-putus dalam pelaksanaannya [10]. Hasil pembelajaran penjaskes 
khususnya atletik pada materi lompat jauh di SD Negeri 2 Katekan Gantiwarno masih rendah hal tersebut bisa dilihat dari hasil evaluasi awal di mana dari 20 siswa hanya $40 \%$ yang memperoleh nilai tuntas sebesar 67 atau hanya 8 siswa dari 20 siswa yang ada. Hasil yang rendah tersebut dikarenakan rendahnya motivasi belajar khususnya pembelajaran lompat jauh. Motivasi ini sangat penting artinya bagi para siswa karena kegiatan yang sudah dirasa tidak menarik untuk dilakukan tanpa adanya pemberian motivasi dari guru penjaskes mustahil para siswa akan dapat melakukan dengan sungguh-sungguh karena lompat jauh ini kegiatan yang monoton dan gerak yang itu-itu saja, sehingga dibutuhkan motivasi yang tinggi dari guru itu sendiri. Di samping rendahnya motivasi juga adanya beberapa fasilitas yang masih sangat kurang seperti media untuk pembelajaran lompat jauh, yang pada umumnya fasilitas ini dikalahkan dengan peralatan yang lain guna menunjang materi akademis, sehingga media belajar bagi siswa yang diperuntukkan untuk menunjang kegiatan olahraga sangat kurang bahkan terkesan seadanya.

Permasalahan yang ada ditambah dengan kurangnya metode pembelajaran yang disampaikan guru terhadap murid, sehingga murid menjadi bosan untuk melakukan apa yang diinstruksikan dari guru itu sendiri. Akibat dari permasalahan yang ada mengakibatkan nilai yang dicapai oleh para siswa rendah atau tidak tuntas menurut batas KKM (Kriteria Ketuntasan Minimal) yaitu untuk lompat jauh 67. Hasil belajar adalah pengukuran dari penilaian usaha belajar, yang dinyatakan dalam bentuk simbol, huruf maupun kalimat yang menceritakan hasil yang sudah dicapai oleh setiap siswa pada periode tertentu. Pengertian ini dapat dilakukan dengan pendidikan. Hasil belajar adalah hasil dari pengukuran terhadap peserta didik yang meliputi faktor kognitif, afektif dan psikomotor setelah mengikuti proses pembelajaran yang diukur dengan menggunakan instrument tes atau instrumen yang relevan.

Syaiful Bahri mengemukakan fungsi-fungsi hasil belajar sebagai berikut: 1) Hasil belajar berupa penilaian. Maksudnya adalah suatu evaluasi pendidikan dapat diartikan sebagai suatu tindakan atau suatu proses untuk menentukan nilai segala sesuatu dalam dunia pendidikan atausegala sesuatu yang berhubungan dengan dunia pendidikan. 2) Hasil belajar sebagai alat motivasi. Dalam proses pembelajaran faktor motivasi memegang peranan yang dominan dimana siswa dalam proses pembelajaran selalu mempunyai kebutuhan yang salah satunya kebutuhan untuk mendapatkan hasil yang baik [11].

Proses pembelajaran akan berhasil sesuai dengan apa yang akan dicapai, perlu memperhatikan faktor yang dapat mempengaruhi hasil belajar. Menurut I Made Sukardi mengemukakan bahwa faktor-faktor keberhasilan belajar terdiri dari faktor internal dan faktor eksternal [12]. Faktor Internal adalah faktor yang menyangkut seluruh diri pribadi, termasuk fisik dan mental yang ikut menentukan berhasil tidaknya seseorang dalam belajar. Faktor Eksternal adalah faktor yang bersumber dari luar individu yang bersangkutan, misalnya ruang belajar yang memenuhi syarat, alat-alat peraga yang memadai dan lingkungan sosial maupun lingkungan alamiahnya. Kedua faktor tersebut dapat mempengaruhi orang yang sedang belajar. Faktor internal dan eksternal dapat mempengaruhi karena dapat mendorong dan dapat pula menghambat seseorang yang sedang belajar. Pada hakekatnya dalam situasi belajar seseorang menghadapi motif dari luar dan lingkungan untuk memperoleh pengalaman. Sumadi Soeryabrata, mengklasifikasikan faktor-faktor belajar sebagai berikut: (1) Faktor-faktor yang berasal dari luar siswa yang dapat digolongkan menjadi dua golongan, yaitu: (a) Faktor-faktor non sosial dan, (b) faktor sosial. (2) Faktor yang berasal dari dalam diri pelajar, yang digolongkan menjadi dua golongan, yaitu: (a) Faktor-faktor fisiologis dan (b) Faktorfaktor psikologis [13].

Untuk mendorong agar siswa memperoleh nilai yang baik perlu ada pembenahan terhadap proses pembelajaran yaitu dengan diadakannya remidi/ perbaikan. Proses pembelajaran yang diharapkan untuk meningkatkan nilai hasil belajar siswa perlu pemberian motivasi terhadap siswa. Motivasi ini penting agar siswa mau melakukan kegiatan pembelajaran dengan semangat tanpa ada beban sehingga siswa akan dengan senang hati mengikuti proses belajar pada kegiatan lompat jauh sebagaimana kegiatan yang lain.

Memberikan motivasi terhadap siswa tidak cukup hanya dengan dorongan semangat tanpa pembenahan sarana dan prasarana yang dibutuhkan oleh guru dan siswa di dalam pelaksanaan pembelajaran. Peningkatan kapasitas guru di dalam mengajar juga sangat penting, karena guru 
harus memberikan inovasi tersendiri terhadap pembelajaran lompat jauh yang semula tidak disukai oleh siswanya agar siswa menjadi mau dan mampu mengikuti instruksi yang diberikan oleh guru dengan senang hati sehingga diharapkan hasil belajar akan meningkat sebagaimana yang diharapkan.

Berdasarkan observasi peneliti, siswa kurang menyukai olahraga atletik karena dianggap menjenuhkan dan tidak ada unsur permainan, siswa lebih menyukai olahraga yang ada unsur permainan seperti bolavoli, sepakbola, ataupun kasti. Peningkatan kapasitas guru terhadap pembelajaran lompat jauh harus selalu diasah dengan cara guru banyak menimba ilmu tentang pembelajaran yang akan disampaikan kepada siswanya. Gerakan lompat jauh dari dulu hingga sekarang masih monoton sehingga perlu dikembangkan dengan proses bermain sebagaimana olahraga permainan, sehingga siswa akan merasa senang dan tidak jenuh, lompat jauh tidak hanya disajikan dengan cara yang sama dan berulang-ulang tanpa ada sentuhan permainan yang mampu membuat siswa tertarik terhadap gerakan lompat jauh.

Salah satu metode pembelajaran yang diterapkan yaitu bermain lompat tali. Menurut Bayu Surya lompat tali dikenal dengan istilah ropeskipping[4]. Skipping adalah suatu aktivitas yang menggunakan tali dengan kedua ujung tali dipegang dengan kedua tangan lalu diayunkan melewati kepala sampai kaki sambil melompatinya. Menurut Chrissie Gallagher lompat tali atau skipping adalah suatu bentuk latihan CV (Cardio Vaskuler) yang sangat baik karena dapat menjadikan sebuah latihan yang sangat berat dan dapat meningkatkan daya tahan dan kecepatan [5]. Diharapkan dengan bermain lompat tali power otot tungkai siswa meningkat.

Berdasarkan latar belakang yang telah disampaikan di atas, hipotesis dalam penelitian ini adalah melalui pendekatan bermain lompat talidapat meningkatkan hasil belajar lompat jauh pada siswa Kelas IV SD Negeri2 Katekan Kecamatan Gantiwarno Kabupaten Klaten Semester II Tahun Pelajaran 2017/2018

Berdasarkan rumusan tersebut maka tujuan dari penelitian ini adalah untuk mendeskripsikan proses peningkatan hasil belajar lompat jauh melalui pendekatan bermain lompat tali pada siswa kelas IV SD Negeri 2 Katekan Kecamatan Gantiwarno Kabupaten Klaten.

\section{Metode Penelitian}

Jenis Penelitian yang akan dilaksanakan adalah penelitian tindakankelas (classroom action research). Penelitian tindakan kelas merupakan suatupencermatan terhadap kegiatan belajar berupa sebuah tindakan, yang sengajadimunculkan dan terjadi dalam sebuah kelas secara bersama (SuharsimiArikunto, 2009: 3) [14].

Prosedur atau langkah-langkah penelitian yang dilakukan terbagi dalam bentuk siklus kegiatan mengacu pada model yang diadopsi dari Hopkins (1993:48), di mana setiap siklus terdiri atas empat kegiatan pokok adalah kegiatan: perencanaan tindakan pelaksanaan, observasi, dan refleksi [15]. Empat kegiatan ini berlangsung secara simultan yang urutannya dapat mengalami modifikasi. Penelitian bertempat SD Negeri 2 Katekan Kecamatan Gantiwarno Kabupaten Klaten. Penelitian dilakukan selama 2 bulan, dari bulan Februari 2018 hingga bulan Maret 2018.

Subjek dalam penelitian ini adalah siswa kelas IV SD Negeri 2 Katekan Kecamatan Gantiwarno Kabupaten Klaten dengan jumlah total 20 orang. Prosedur penelitian yang meliputi perencanaan tindakan, pelaksanaan tindakan, pengamatan dan refleksi akan diuraikan sesuai dengan siklusnya masing-masing. Pendiskripsian dimaksudkan agar dapat diperoleh gambaran yang jelas dan menyeluruh tentang pelaksanaan PTK ini. Dalam penelitian ini terdapat dua siklus.

Tabel 1. Teknik Pengumpulan Data

\begin{tabular}{|c|c|c|c|c|}
\hline No & Sumber Data & Jenis Data & $\begin{array}{c}\text { Teknik } \\
\text { Pengumpulan }\end{array}$ & Instrumen \\
\hline 1 & Siswa & $\begin{array}{l}\text { Jumlah siswa yang } \\
\text { dapat melakukan } \\
\text { lompatan }\end{array}$ & Melaksanakan tes & $\begin{array}{l}\text { Lembar } \\
\text { Penilaian }\end{array}$ \\
\hline
\end{tabular}




\begin{tabular}{|c|c|c|c|c|}
\hline 2 & Guru & $\begin{array}{l}\text { Langkah-langkah } \\
\text { pembelajaran }\end{array}$ & Observasi & $\begin{array}{l}\text { Lembar } \\
\text { Observasi } \\
\text { Pengamatan }\end{array}$ \\
\hline 3 & Guru dan Siswa & $\begin{array}{l}\text { Aktivitas guru dan } \\
\text { siswa selaam } \\
\text { pembelajaran }\end{array}$ & Observasi & $\begin{array}{l}\text { Proses } \\
\text { Pembelajaran }\end{array}$ \\
\hline 4 & Siswa & $\begin{array}{l}\text { Respon siswa } \\
\text { terhadap metode } \\
\text { pembelajaran yang } \\
\text { digunakan }\end{array}$ & $\begin{array}{l}\text { Penyebaran } \\
\text { kuesioner }\end{array}$ & $\begin{array}{l}\text { Angket/ } \\
\text { kuesioner } \\
\text { tanggapan } \\
\text { siswa }\end{array}$ \\
\hline
\end{tabular}

Data yang diperoleh pada penelitian ini dianalisis dengan menggunakan diskriptif komparatif yaitu dengan membandingkan data kuantitatif dari kondisi awal, siklus I, siklus II. Indikator keberhasilan bersumber pada hasil yang diperoleh dari pre test dan post test yang mencerminkan pemahaman siswa pada konsep yang dibelajarkan diharapkan adanya peningkatan pemahaman sesuai nilai yang diperoleh oleh masing-masing siswa. Minimal 75\% dari jumlah siswa mencapai hasil belajar tuntas $(\mathrm{KKM}=67)$. Sumber data pada penelitian ini berupa data kuantitatif diperoleh dari subjek penelitian berupa data nilai hasil penilaian unjuk kerja lompat jauh siswa.

\section{Hasil dan Pembahasan}

\section{a. Hasil Penelitian}

Hasil penelitian ini didasarkan atas hasil pengamatan dan dilanjutkan refleksi masingmasing siklus, sebagai berikut:

1) Pra Penelitian

Penelitian yang dilaksanakan di kelas IV SD Negeri 2 Katekan Kecamatan Gantiwarno Kabupaten Klaten diawali dengan kegiatan observasi bagaimana cara siswa melakukan lompat jauh dan cara mengajar guru. Observasi ditujukan untuk mengetahui bagaimana cara guru mengajarkan lompat jauh dan bagaimana cara siswa melakukan gerakan lompat jauh.

Hasil tes awal yang dilakukan pada siswa kelas IV SD Negeri 2 Katekan jumlah siswa 20, baru 8 siswa yang tuntas KKM, yaitu 67 untuk penjasorkes yang tercantum dalam Kurikulum Tingkat Satuan Pendidikan (KTSP) kelas IV SD Negeri 2 Katekan. Kegiatan pratindakan ini dilakukan oleh 20 siswa.

Berdasarkan hasil tes pratindakan diperoleh nilai rata-rata sebesar 55,94. Jumlah siswa yang mencapai KKM hanya sebanyak 8 siswa (40\%) dan siswa yang belum mencapai KKM sebanyak 12 siswa $(60 \%)$. Dari tes pratindakan yang dilakukan diketahui bahwa ada beberapa siswa yang tidak mampu untuk melakukan lompat jauh dengan benar baik dari awalan, tumpuan, saat melayang, dan mendarat.

Berdasarkan data yang diperoleh dari tes pratindakan, peneliti, dan guru bermaksud untuk memperbaiki dan meningkatkan kemampuan siswa dalam melakukan lompat jauh.

2) Siklus I

Dari hasil pengamatan yang dilakukan kolaborator terhadap proses pembelajaran, setiap kemajuan yang terjadi baik pada siswa maupun suasana pembelajaran dicatat dan diperoleh sebagai berikut:

a. Guru peneliti sudah melaksanakan pembelajaran sesuai dengan RPP.

b. Siswa masih ragu-ragu dan belum siap melakukan bermain lompat bilah bambu dan lompat kardus.

c. Hasil dari diskusi dan tanya jawab setelah melihat dan melakukan lompatan diperoleh jawaban sebagai berikut:

1) Berlatih melompati tali karet sesering mungkin.

2) Awalan dilakukan dengan kecepatan maksimal. 
3) Melompat dengan tumpuan satu kaki.

4) Mendarat dengan dua kaki bersama sama dengan kedua tangan diayunkan dari atas ke depan.

d. Siswa belum terbiasa mengambil kesimpulan dari kegiatan yang dilakukan.

e. Pada saat bermain dan diskusi masih didominasi satu atau dua anak belum semua siswa berani mengeluarkan pendapatnya.

f. Masih ada materi yanng sulit dikuasai oleh siswa

Berdasarkan hasil observasi peneliti dan kolabolator melakukan refleksi sebagai berikut:

a. Guru lebih aktif mengawasi kegiatan siswa dan memancing partisipasi dalam mengikuti pembelajaran.

b. Siswa dipersiapkan terlebih dahulu dengan menyampaikan tugas tugas secara rinci dan lengkap sesuai dengan rencana.

c. Hasil belajar lompat jauh meningkat ditandai dengan 12 anak tuntas dibandingkan dengan keadaan sebelum siklus hanya 8 siswa yang tuntas.

d. Sebagian siswa masih asing dengan permainan lompat bilah bambu dan lompat kardus karena terbiasa dengan latihan lompat jauh sistem drill yang berulang ulang.

e. Siswa belum maksimal dalam melaksanakan diskusi dan tanya jawab.

f. Peneliti perlu mengawasi siswa secara secara teliti dan cermat.

g. Peneliti belum maksimal dalam mengarahkan siswa dalam permainan.

Berdasarkan hasil tes siklus I diperoleh nilai rata-rata sebesar 65,63. Jumlah siswa yang mencapai KKM hanya sebanyak 12 siswa (60\%) dan siswa yang belum mencapai KKM sebanyak 8 siswa (40\%). Hasil belajar lompat jauh menunjukkan masih ada beberapa siswa yang masih mengalami kesulitan terutama dalam melakukan gerakan tolakan melayang di udara dan mengayunkan tangan dari atas ke depan. Karena pada siklus I siswa belum memenuhi ketercapaian KKM, yaitu sebesar $80 \%$ siswa yang tuntas, maka penelitian dilanjutkan pada siklus II.

3) Siklus II

Hasil pengamatan kolaborator terhadap pembelajaran pada siklus II ini diperoleh hasil sebagai berikut:

a. Seluruh peserta didik sudah dapat melakukan permainan lompat jauh dengan melompat sasaran ke arah ban sepeda dan melompati tali gelang karet. Mereka melakukan gerakan lompat jauh dengan gembira dan penuh semangat.

b. Adanya peningkatan aktivitas yang efektif dari peserta didik pada setiap tindakan, hal ini dimungkinkan karena guru telah mengkondisikan pembelajaran dengan strategi yang baik sehingga peserta didik dapat melakukan aktivitasnya tanpa diberi contoh mereka melakukan kegiatan secara mandiri.

Dari hasil sharing ideas dari kolabolator tentang pelaksanaan proses pembelajaran dan hasil belajar yang diperoleh dari releksi sebagai berikut:

a. Peserta didik sudah mulai terbiasa dengan pendekatan bermain yang digunakan dalam pembelajaran.

b. Peserta didik lebih bersemangat aktif dan kreatif dalam proses pembelajaran.

c. Peneliti semakin mengerti kelemahan dan terus mencari alternatif pemecahannya.

d. Kegiatan pembelajaran menjadi sesuatu yang sangat digemari oleh siswa karena siswa asyik dengan permainan dan tidak merasa bosan.

Dari hasil tes belajar siswa setelah melalui refleksi siklus I dan siklus II maka diperoleh data hasil belajar lompat jauh siswa siswa kelas IV SD Negeri 2 Katekan Kecamatan Gantiwarno Kabupaten Klaten meningkat dengan ditandai sebanyak 18 siswa mendapatkan nilai di atas KKM.

b. Pembahasan

Pada siklus I dilakukan pembelajaran dengan melaksanakan lompat jauh dalam bentuk permainan lompat tali. Permainan ini menekankan pada masalah tehnik awalan, tumpuan, melayang, dan mendarat. Pada siklus I ini guru peneliti sudah melaksanakan 
pembelajaran sesuai dengan RPP, akan tetapi siswa masih ragu-ragu dan belum siap melakukan kegiatan bermain dalam bentuk permainan lompat bilah bambu dan lampat kardus. Hasil diskusi dan tanya jawab diperoleh kesimpulan bahwa siswa masih perlu berlatih melompati tali sesering mungkin.

Pada pelaksanaan tindakan ternyata siswa belum terbiasa mengambil kesimpulan dari kegiatan yang dilakukan, pada saat bermain dan berdiskusi juga masih didominasi oleh satu atau dua orang siswa dan masih ada materi yang belum di kuasai oleh siswa. Pada siklus II dilakukan pembelajaran lompat jauh dengan pendekatan bermain menggunakan permainan lompat ban sepeda dan lompat tali gelang karet sesuai dengan refleksi pada siklus I, proses pembelajaran berlangsung dinamis, dan menyenangkan guru dan siswa melaksanakan pembelajaran dengan gembira. Siswa aktif melakukan kegiatan permainan dan saling bertukar pikiran dengan kelompoknya maupun antar kelompok.

Pada pelaksanaan siklus II, diketahui siswa sudah dapat melakukan kegiatan bermain dan lompat jauh dengan gembira dan penuh semangat dengan peningkatan aktivitas yang efektif dengan ditandai adanya peningkatan hasil belajar siswa dengan ketuntasan mencapai 90\%. Dari jumlah siswa kelas IV SD Negeri 2 Katekan Kecamatan Gantiwarno Kabupaten Klaten sebanyak 18 sudah mendapatkan nilai hasil belajar di atas batas nilai KKM yaitu 67 sesuai dengan KTSP SD Negeri 2 Katekan Kecamatan Gantiwarno Kabupaten Klaten Semester II Tahun Pelajaran 2018/2019.

Setelah dilakukan penelitian tindakan selama 2 siklus dan setiap siklus dilakukan tes untuk memperoleh hasil belajar lompat jauh, maka di peroleh data sebagai berikut: Dari hasil refleksi diketahui bahwa pada siklus I siswa masih ragu ragu dan belum memahami pola pembelajaran lompat jauh dengan pendekatan bermain. Pelaksanaan pembelajaran belum maksimal masih ada siswa yang tidak memperhatikan pembelajaran dan ada beberapa materi yang belum dikuasai oleh beberap siswa. Walaupun guru sudah melakukan perannya sesuai dengan perencanaan dan model pembelajaran sudah tepat, secara keseluruhan tujuan pembelajaran belum tercapai sesuai rencana.

Dari hasil sharing ideas dengan kolaborator tentang pelaksanaan proses pembelajaran dan hasil belajar pada siklus II diperoleh hasil refleksi: siswa sudah mulai terbiasa dengan pembelajaran yang menggunakan pendekatan bermain siswa lebih semangat aktif dan kreatif dalam proses pembelajaran. Guru peneliti semakin mengerti kelemahannya dan terus mencari alternatif pemecahannya proses pembelajaran sudah sesuai dengan RPP dan guru sudah melakukan perannya sesuai dengan model pembelajaran yang ditetapkan secara keseluruhan tujuan pembelajaran sudah tercapai sesuai dengan rencana setelah dilakukan tindakan siklus II yang merupakan refleksi dari siklus I pada siklus II hasil pembelajaran lompat jauh siswa mengalami peningkatan hingga 18 siswa (90\%) mendapat nilai di atas batas KKM dan dinyatakan tuntas.

Upaya peningkatan hasil belajar lompat jauh berhasil dengan baik jika dilihat dari peningkatan pada tiap siklus yang rata-rata mencapai ketuntasan pada setiap tindakan siklus peningkatan hasil belajar yang paling besar pada siklus ke II hal ini terjadi karena siswa sudah mulai memahami konsep pembelajaran lompat jauh dengan pendekatan bermain dan merasa senang dalam mengikuti pembelajaran sehingga hasil yang diperoleh siswa meningkat dan proses pembelajaran sudah berjalan sesuai dengan rencana dan mendapat hasil sesuai dengan yang diharapkan.

\section{Kesimpulan}

Setelah dilakukan penelitian tindakan kelas dengan dua siklus dan dilakukan analisis dapat disimpulkan bahwa upaya peningkatan hasil lompat jauh melalui bermain lompat tali pada siswa kelas IV SD Negeri 2 Katekan Kecamatan Gantiwarno Kabupaten Klaten telah berhasil ditandai dengan peningkatan nilai rata-rata siswa. Nilai rata-rata siswa pada kegiatan pratindakan sebesar 55,94 dengan persentase ketuntasan sebesar 40\%. Kondisi tersebut mengalami peningkatan nilai rata-rata siswa pada siklus I yaitu menjadi sebesar 65,63 dan persentase ketuntasan sebesar $60 \%$. Namun, peningkatan tersebut masih belum mencapai 
target yang ditetapkan sebelumnya. Kemudian setelah melanjutkan ke siklus II nilai rata-rata lompat jauh siswa kembali mengalami peningkatan menjadi sebesar 70,50 dengan persentase ketuntasan sebesar 90\%. Hal tersebut menunjukkan bahwa target yang telah ditetapkan sebelumnya sudah tercapai sehingga penelitian dihentikan pada siklus II. Proses pembelajaran lompat jauh menggunakan pendekatan bermain berlangsung dinamis dan menyenangkan. Peserta didik aktif melaksanakan tugas dan mengamati gerakan teknik lompat jauh dan saling diskusi dengan teman. Seluruh aspek penilaian dikuasai peserta didik. Kemampuan lompat jauh peserta didik meningkat dengan ditandai dengan seluruh peserta didik tuntas KKM (Kriteria Ketuntasan Minimal) yaitu 67.

\section{Referensi}

[1] Udin S Winataputra, M.A., dkk. (2004). Strategi Belajar Mengajar. Jakarta: Universitas Terbuka.

[2] Rusli Lutan. (2004). Strategi Pembelajaran Penjas. Jakarta: Universitas Terbuka.

[3] Yudha M. Saputra. (2001). Teori Bermain. Jakarta. Depdiknas.

[4] Bayu Surya. (2010). Skipping. Diakses dalam (http://bayumuhammad. blogspot.com/2010//).

[5] Chrissie Gallagher. (2006). Skipping. Diakses dalam (http://.

ChrissieGallagherblogspot.com/2006//).

[6] Muhamad Muhyi Faruq. (2009). Tujuan Lompat Tali. (http://MuhyiFaruq. blogspot. com/2010//).

[7] Soetoto Pontjopoetro. (2002). Lompat Tali. (http://indoshvong.blogspot. com/2010//).

[8] Eddy Purnomo. (2007). Gerak Dasar Atletik. Universitas Negeri Yogyakarta.

[9] Sajoto. (1988). Peningkatan dan Pembinaan Kekuatan Kondis Fisik Dalam Olahraga, Semarang, Dahara Prize.

[10] Murniasari. (2008). Atletik. Jakarta: Ganeka.

[11] Syaiful Bahri. (1994). Strategi Pembelajaran. Jakarta: Depdiknas.

[12] I Made Sukardi. (1983). Bimbingan Penyuluhan. Surabaya: Usaha Nasional.

[13] Sumadi Suryabrata. (2002). Belajar dan Pembelajaran. Jakarta: Rajawali Pers.

[14] Suharsimi Arikunto. (2002). Penelitian Suatu Pendekatan Praktik. Jakarta: PT. Rineka Cipta.

[15] Hopkins. (1993).. Teaching Writing: Balancing Process and Product. New York: Maxwell Mac Millan Inc 